\title{
Epibenthic communities of trawlable grounds of the Cantabrian Sea
}

\author{
ALBERTO SERRANO $^{1}$, FRANCISCO SÁNCHEZ ${ }^{1}$ and GERARDO GARCÍA-CASTRILLO ${ }^{2}$ \\ ${ }^{1}$ Instituto Español de Oceanografía de Santander, P.O. Box 240, 39080, Santander, Spain. E-mail: aserrano@st.ieo.es \\ ${ }^{2}$ Museo Marítimo del Cantábrico de Santander, Spain.
}

\begin{abstract}
SUMMARY: Epibenthic communities of the Cantabrian shelf were sampled in October 2000 and October 2001 using a $3.5 \mathrm{~m}$ beam trawl. The surveys were undertaken following a pattern of stratified sampling in four transects perpendicular to the coastline and included three depth strata $(30-100,101-200,201-400 \mathrm{~m})$. The total number of species collected was 241, belonging to 9 taxa, of which the best represented were molluscs and crustaceans. Longitudinal differences in ecological indices were detected in relation to biogeographical and hydrographic patterns. Three main assemblage groups were identified using cluster analysis. The effect of environmental variables (depth, near-bottom temperature and salinity, sediment morphology, Atlantic influence) on assemblages was also identified by canonical ordination, showing a pattern of two gradients: depth/water temperature and sediment characteristics. Assemblages identified by both methods were spatially coherent. The hermit crab Diogenes pugilator typifies the poor fine sands of the inner shelf; fishes (Arnoglossus laterna, Callyonimus maculatus, Pomatochistus sp.) and a hermit crab, Anapagurus laevis, characterise the assemblage of inner and middle shelf sediments with higher organic content, and the echinoderm Ophiura affinis, the fish Lepidorhombus boscii and Crangonidae Crustacea typify the deeper community of medium and fine sediments with intermediate levels of organic content.
\end{abstract}

Keywords: epibenthic communities, faunal assemblages, Cantabric Sea, beam trawl, canonical ordination.

RESUMEN: COMUNIDADES EPIBENTÓNICAS DE LAS PLAYAS DE ARRASTRE DEL MAR CANTÁBRICO. - Las comunidades epibentónicas del mar Cantábrico fueron muestreadas en octubre de 2000 y 2001 usando un bou de vara de 3.5 m. Las campañas se realizaron siguiendo un muestreo estratificado en 4 transectos perpendiculares a la costa, con 3 estratos batimétricos (30$100,101-200,201-400 \mathrm{~m})$. Un total de 241 especies fueron identificadas, pertenecientes a 9 taxa, de los cuales los mejor representados fueron Moluscos y Crustáceos. Se detectaron diferencias longitudinales en los índices ecológicos, en relación a factores biogeográficos e hidrográficos. Mediante un dendrograma se identificaron 3 agrupaciones principales. El efecto de las variables ambientales (profundidad, temperatura y salinidad, morfología sedimentaria, influencia atlántica) sobre las agrupaciones fue identificado mediante análisis canónico, mostrando un patrón con 2 gradientes: profundidad/temperatura y características sedimentarias. Las agrupaciones identificadas por ambos métodos son espacialmente coherentes. El cangrejo ermitaño Diogenes pugilator caracteriza las arenas finas pobres de la plataforma interna; especies de peces (Arnoglossus laterna, Callyonimus maculatus, Pomatochistus sp.) y otro ermitaño, Anapagurus laevis, caracterizan la agrupación de plataforma interna y media con sedimentos de alto contenido orgánico, mientras que el equinodermo Ophiura affinis, el pez Lepidorhombus boscii y crustáceos Crangonidae tipifican la comunidad de más profundidad con sedimentos finos y medios y niveles intermedios de materia orgánica.

Palabras clave: comunidades epibentónicas, agrupaciones faunísticas, bou de vara, ordenación canónica.

\section{INTRODUCTION}

The Cantabrian Sea area is located in the subtropical/boreal transition zone of the eastern Atlantic. Due to this location, its fauna is composed of typical temperate water species from the south together with others of northern origin, and is therefore characterised by high biodiversity indices in comparison with adjacent areas (Olaso, 1990; Sánchez, 1993). In addition, the topographical com- 
plexity and the wide range of substrates on its narrow continental shelf give rise to many different types of habitats. This environmental variability over the narrowest surface of the Cantabrian Sea shelf produces strong environmental gradients over a short distance. Previous papers have described how depth and bottom type are the main determining factors (Basford et al., 1989; Olaso, 1990; Zendrera, 1990; Sánchez, 1993). At the same time, there is a longitudinal gradient because the Atlantic influence in the western area of the Cantabrian Sea is considered to diminish towards the eastern part of the Bay of Biscay.

The Cantabrian shelf is subject to strong fishing pressure affecting not only the target or commercial species, but also the structure of the ecosystem. Knowledge of the communities inhabiting this area is of great importance both for assessing possible changes in the structure of the ecosystem as a consequence of trawling and for putting into practice multispecific resource management systems requiring quantified data on all the species present in the ecosystem. New resource management tools require more detailed information on target species, and also on all the species present in the ecosystems inhabited by commercial species.

The Cantabrian shelf demersal communities have been sampled yearly since 1983 using bottom trawl surveys conducted by the Instituto Español de Oceanografía. These surveys use an otter trawl sampler (baca 44/60) with a cod end mesh of $20 \mathrm{~mm}$ and a horizontal opening of $18.9 \mathrm{~m}$, thus giving information on demersal and benthic megafauna (Olaso, 1990; Sánchez, 1993; Sánchez et al., 1995; García-Castrillo and Olaso, 1995; Sánchez and Serrano, 2003).

A new sampling experiment on epibenthic communities of the Cantabrian shelf was carried out in October 2000 and October 2001 with a beam trawl sampler. This paper analyses the structure and composition of epibenthic communities living over the continental shelf of the Cantabrian Sea and the influence certain environmental variables have on them.

\section{MATERIALS AND METHODS}

The study area includes the Cantabrian shelf from Ribadeo $\left(7.0^{\circ} \mathrm{W}\right)$ to Guetaria $\left(2.2^{\circ} \mathrm{W}\right)$ between 30 and $400 \mathrm{~m}$ depth (Fig. 1). Four transects perpendicular to the coast (1=Ribadeo; 2=Gijón; $3=$ Santander; $4=$ Guetaria $)$ and 3 depth strata $(\mathrm{A}=30$ $100 \mathrm{~m} ; \mathrm{B}=101-200 ; \mathrm{C}=201-400)$ were determined. Each depth stratum from the 4 transects was sampled in October 2000 and October 2001, except strata $1 \mathrm{~A}$ and $4 \mathrm{C}$ in 2000 due to rough seas. The total number of samples obtained was 22 .

The sampler used was a beam trawl with a horizontal opening of $3.5 \mathrm{~m}$, a vertical opening of $0.6 \mathrm{~m}$, and a mesh size of $9 \mathrm{~mm}$. The mean trawling speed was 2.5 knots, with a haul duration of 15 minutes from ground contact, monitored by a Scanmar net control system. The mean swept area was of $4099.9 \mathrm{~m}^{2}$, with a standard deviation of $380.4 \mathrm{~m}^{2}$.

Data were expressed in terms of number of individuals per $1000 \mathrm{~m}^{2}$. For the multivariate analysis, data were log-transformed to minimise the effect of high values and satisfy data normality (Jongman et al., 1987; Krebs, 1989). The decapod Polybius henslowii was removed from the matrices due to its semipelagic behaviour.

To determine the influence of environmental variables on epibenthic communities, temperature and salinity data were taken using a CTD Seabird 25. Sedimentary characteristics were determined in each haul, using a box-corer only in the 2001 survey, except in $2 \mathrm{C}$ and $4 \mathrm{~B}$, which could not be sampled due

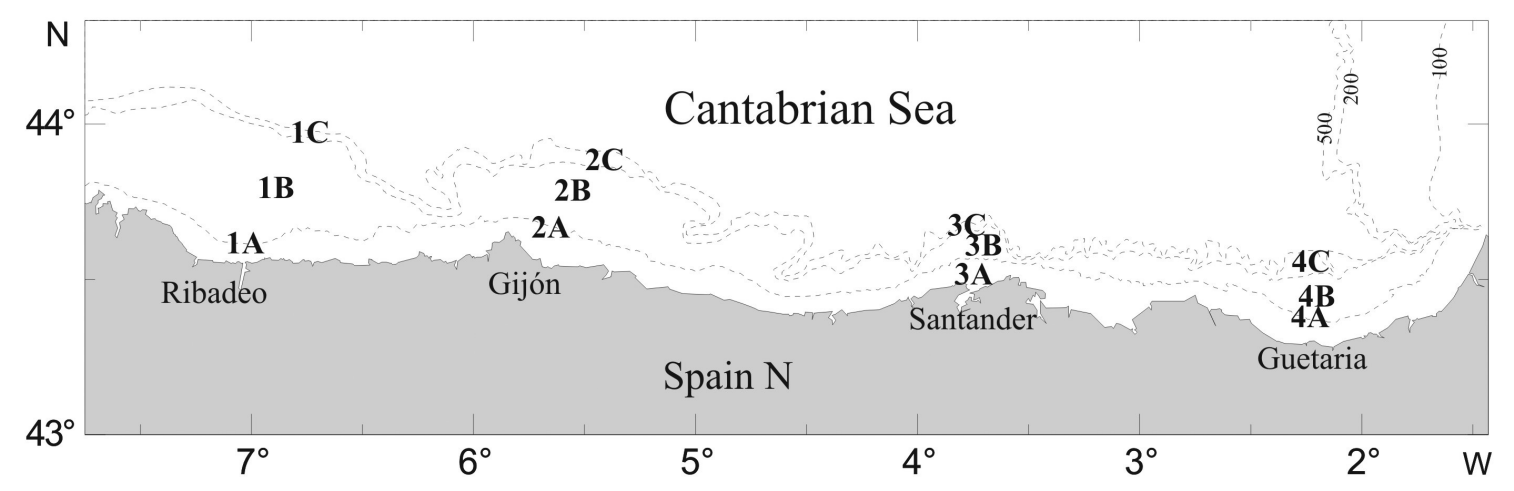

FIG. 1. - Study area and sampling stations by transect and depth strata 
TABLE 1. - Characteristics of hauls performed in 2000-2001 and mean values of ecological indices ( \pm standard deviation) for depth strata and sector. Mean depth values between surveys $(\mathrm{m})$ and sediment parameters; $\mathrm{Q}_{50}=$ mean particle diameter $(\mathrm{mm})$; GCS $=$ weight percentage of gravel and coarse sands $(>500 \mu \mathrm{m})$; MFS = weight percentage of medium, fine and very fine sands $(63-500 \mu \mathrm{m})$; Silt $=$ weight percentage of silt $(<63 \mu \mathrm{m}) ; \mathrm{S}_{0}=$ sorting coefficient; \%OM= weight percentage of organic matter; $\mathrm{S}=$ number of species by haul; $\mathrm{N}=$ number of individuals by $1000 \mathrm{~m}^{2} ; \mathrm{H}^{\prime}=$ Shannon-Wiener diversity index

\begin{tabular}{|c|c|c|c|c|c|c|c|c|c|c|c|}
\hline Stratum & Sector & Depth & $\mathrm{Q}_{50}$ & GCS & MFS & Silt & $\mathrm{S}_{0}$ & $\% \mathrm{OM}$ & $S$ & $\mathrm{~N}$ & $\mathrm{H}^{\prime}$ \\
\hline A & $\begin{array}{l}1 \\
2 \\
3 \\
4\end{array}$ & $\begin{array}{l}100 \\
96 \\
41 \\
98\end{array}$ & $\begin{array}{l}0.144 \\
0.165 \\
0.200 \\
0.233\end{array}$ & $\begin{array}{c}1.4 \\
3.3 \\
3.1 \\
28.0\end{array}$ & $\begin{array}{l}81.4 \\
87.7 \\
96.2 \\
39.1\end{array}$ & $\begin{array}{c}17.2 \\
7.7 \\
0.1 \\
20.3\end{array}$ & $\begin{array}{l}1.47 \\
1.27 \\
1.29 \\
4.44\end{array}$ & $\begin{array}{l}1.85 \\
5.00 \\
2.20 \\
5.60\end{array}$ & $\begin{array}{l}28.0 \pm * \\
28.5 \pm 3.5 \\
23.5 \pm 6.4 \\
62.5 \pm 4.9\end{array}$ & $\begin{aligned} 75.4 & \pm * \\
4723.6 & \pm 2466.2 \\
91.4 & \pm 53.6 \\
3257.5 & \pm 3890.5\end{aligned}$ & $\begin{array}{l}3.06 \pm * \\
0.59 \pm 0.08 \\
2.26 \pm 0.16 \\
1.99 \pm 2.07\end{array}$ \\
\hline B & $\begin{array}{l}1 \\
2 \\
3 \\
4\end{array}$ & $\begin{array}{l}141 \\
164 \\
188 \\
138\end{array}$ & $\begin{array}{c}0.077 \\
0.283 \\
0.213 \\
-\end{array}$ & $\begin{array}{c}2.4 \\
10.2 \\
4.9 \\
-\end{array}$ & $\begin{array}{c}51.4 \\
89.7 \\
93.6 \\
-\end{array}$ & $\begin{array}{c}46.2 \\
0.0 \\
0.9 \\
-\end{array}$ & $\begin{array}{l}2.26 \\
1.41 \\
1.37 \\
-\end{array}$ & $\begin{array}{l}3.28 \\
8.49 \\
7.08 \\
-\end{array}$ & $\begin{array}{l}50.0 \pm 2.8 \\
55.0 \pm 5.7 \\
32.5 \pm 9.2 \\
40.5 \pm 0.7\end{array}$ & $\begin{array}{c}178.5 \pm 27.4 \\
382.6 \pm 121.3 \\
81.6 \pm 25.3 \\
319.1 \pm 5.9\end{array}$ & $\begin{array}{l}3.79 \pm 0.05 \\
3.64 \pm 1.25 \\
3.72 \pm 0.59 \\
3.24 \pm 0.85\end{array}$ \\
\hline $\mathrm{C}$ & $\begin{array}{l}1 \\
2 \\
3 \\
4\end{array}$ & $\begin{array}{l}300 \\
291 \\
262 \\
354\end{array}$ & $\begin{array}{c}0.177 \\
- \\
0.274 \\
0.095\end{array}$ & $\begin{array}{c}2.2 \\
- \\
10.6 \\
6.0\end{array}$ & $\begin{array}{c}82.4 \\
- \\
86.4 \\
65.7\end{array}$ & $\begin{array}{c}15.4 \\
- \\
2.0 \\
26.4\end{array}$ & $\begin{array}{c}1.37 \\
- \\
1.49 \\
1.66\end{array}$ & $\begin{array}{c}2.80 \\
- \\
7.01 \\
2.20\end{array}$ & $\begin{array}{l}42.5 \pm 6.4 \\
39.5 \pm 3.5 \\
32.5 \pm 20.5 \\
25.0 \pm *\end{array}$ & $\begin{array}{c}672.0 \pm 442.1 \\
250.1 \pm 135.3 \\
5953.9 \pm 8389.4 \\
150.5 \pm *\end{array}$ & $\begin{array}{l}2.27 \pm 0.32 \\
3.91 \pm 013 \\
1.99 \pm 1.82 \\
3.68 \pm *\end{array}$ \\
\hline
\end{tabular}

to rough seas. Median particle size $\left(\mathrm{Q}_{50}\right)$, sorting coefficient $\left(\mathrm{S}_{0}\right)$, the weight percentages of gravel and coarse sands $(>500 \mu \mathrm{m})$, medium, fine and very fine sands $(63-500 \mu \mathrm{m})$, and silt $(<63 \mu \mathrm{m})$, and the weight percentage of organic matter were determined.

Similarity between samples was calculated using the Bray-Curtis index (Clarke and Warwick 1994; Field et al., 1982) and the resultant dendrogram was obtained with the Group Average clustering algorithm using the PRIMER ${ }^{\odot}$ package. The contribution of each species to the similarity of the cluster groups of samples was determined using the SIMPER (similarity percentages) routine.

The effect of environmental variables on communities was appreciated using canonical correspondence analysis, CCA (Jongman et al., 1987; Ter Braak, 1987 and 1988; Ter Braak and Verdonschot, 1995). The abiotic variables used in the analysis were depth, near-bottom temperature, near-bottom salinity, temperature and salinity at $50 \mathrm{~m}$ (with the aim of identifying the effect of hydrographical anomalies), western longitude (Atlantic influence), and sediment characteristics. The representativeness of the ordination analysis is given in terms of eigenvalues of the axes and of variance explained by the biplots, and the statistical significance was calculated by the Monte Carlo test (Verdonschot and Ter Braak, 1994).

\section{RESULTS}

A total of 241 species belonging to 9 taxa were identified (see Appendix 1), of which the best repre- sented were molluscs (59 species) and crustaceans (55). The remaining groups were fishes (44 species), Polychaeta (27), Cnidaria (22), Echinodermata (22), Porifera (9), Sipuncula (2) and Tunicata (1).

A great variability was found in the dominant species by station. In the shallowest stratum, the hermit crab Anapagurus laevis was the most abundant species at stations $1 \mathrm{~A}$ and $2 \mathrm{~A}$, with a massive abundance in the latter; another hermit crab, Diogenes pugilator, was dominant at $3 \mathrm{~A}$, as is the gasteropod Turritella communis at 4A (massive abundance). The 101-200 stratum was dominated by fish species: Arnoglossus laterna at 1B, Pomatochistus sp. at 2B and Gadiculus argenteus at 3B and 4B. In the deepest stratum, the anthozoans Epizoanthus papillosus and Cariophyllia smithii dominated at stations 1C and $3 \mathrm{C}$ respectively, while the shrimp Plesionika heterocarpus was the most abundant species at stations $2 \mathrm{C}$ and $4 \mathrm{C}$.

The mean values of the ecological indices related to depth and sediment parameters at each station (mean values between surveys) are shown in Table 1. Stratum B was the richest in all transects, except 4, where richness decreased with depth. As a general pattern, an increase in the number of species towards the east was observed in the shallowest stratum, and towards the west in the deepest.

The abundance (number of individuals by $1000 \mathrm{~m}^{2}$ ) and diversity did not follow clear patterns, albeit for the obvious reason that great abundances correspond to low diversities. The three stations with highest abundances and lower diversity are those in which one species appeared massively. These were 2A (A. laevis, $90 \%$ of total abundance 


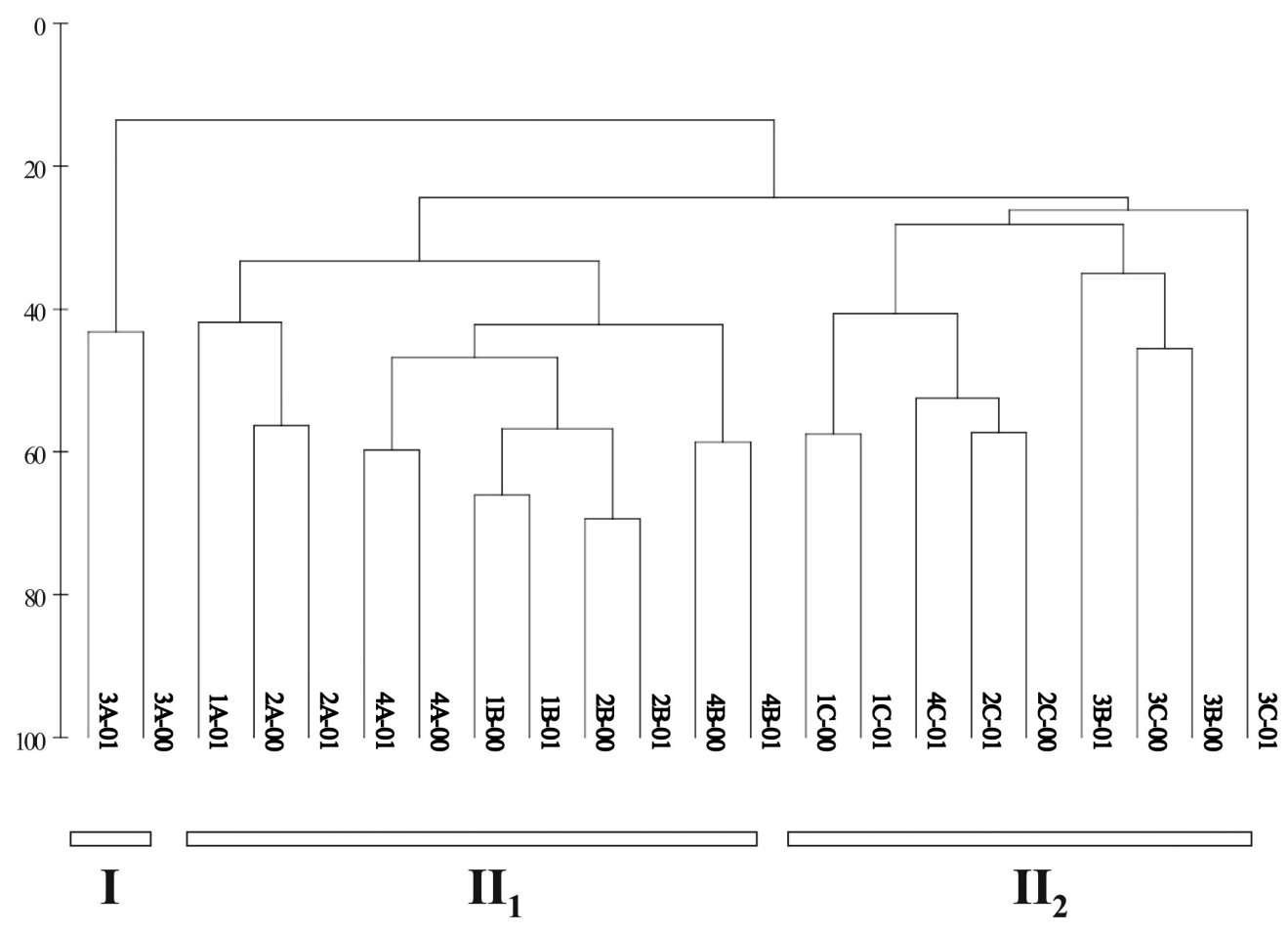

FIG. 2. - Dendrogram showing the clustering of hauls, using the Bray-Curtis similarity index

N), 4A (T. communis, 89\% N) and 3C (C. smithii, $89 \% \mathrm{~N}$ ). These stations showed high values of organic material and percentages of gravel and coarse sand. There were no clear connection patterns between the sedimentary variables and indices, although in some cases coincidences can be seen between high percentages of silt and richness, and high values of coarse sediments and low diversities. An interannual variability in abundance was also patent, as inferred by the high values of standard deviation, mainly at those stations which showed higher abundances. Variability was not so high in richness and diversity, with the exception of station $3 \mathrm{C}$, where the huge abundance of $C$. smithii was only observed in the year 2000 .

In the dendrogram of samples (Fig. 2) it can be seen how pairs of hauls from the same station are grouped in all cases, except for station $3 \mathrm{C}$, in which the differentiation between samples has already been cited. This shows a maintenance of the faunistic assemblages throughout the study period, despite the differences in abundance cited in the previous point.

The clustering discriminates samples from station 3A (group I, Fig. 2), which is the shallowest. This station is typified by the two hermit crab species, A. laevis and D. pugilator, together with
TABLE 2. - SIMPER results: species typifying groups (5 more discriminant). Av.N: mean abundance in the group (ind. $1000 \mathrm{~m}^{-2}$ ); $\operatorname{Sim}(\%)$ : percentage of similarity explained; $\operatorname{C.Sim}(\%)$ : cumulative percentage of similarity $(\%)$

\begin{tabular}{|c|c|c|c|}
\hline & Av.N & $\operatorname{Sim}(\%)$ & C. $\operatorname{Sim}(\%)$ \\
\hline \multicolumn{4}{|c|}{ Group I - Average similarity: 43.20} \\
\hline Diogenes pugilator & 55.0 & 30.22 & 30.22 \\
\hline Anapagurus laevis & 9.8 & 18.90 & 49.13 \\
\hline Arnoglossus laterna & 5.0 & 16.96 & 66.09 \\
\hline Pomatochistus sp & 0.9 & 8.48 & 74.56 \\
\hline Buglossidium luteum & 0.9 & 8.48 & 83.04 \\
\hline \multicolumn{4}{|c|}{ Group $\mathrm{II}_{1}$ - Average similarity : 41.82} \\
\hline Arnoglossus laterna & 29.9 & 10.77 & 10.77 \\
\hline Callyonimus maculatus & 25.7 & 10.24 & 21.01 \\
\hline Pomatochistus sp. & 36.0 & 6.30 & 27.31 \\
\hline Anapagurus laevis & 798.2 & 4.76 & 32.07 \\
\hline Gaidropsarus macrophthalmus & 4.1 & 3.70 & 35.76 \\
\hline \multicolumn{4}{|c|}{ Group $\mathrm{II}_{2}$ - Average similarity : 33.63} \\
\hline Ophiura affinis & 78.4 & 8.69 & 8.69 \\
\hline Lepidorhombus boscii & 6.8 & 8.07 & 16.76 \\
\hline Philocheras echinulatus & 9.9 & 6.20 & 22.96 \\
\hline Pontophilus spinosus & 10.1 & 5.23 & 28.19 \\
\hline Munida sarsi & 11.7 & 4.93 & 33.12 \\
\hline
\end{tabular}

several fish species (Table 2). Table 3 shows the species whose differences in abundance between groups lead to this dichotomy. The crustacean $D$. pugilator was exclusive to station $3 \mathrm{~A}$, and the remaining species were less abundant at this station than at the other ones (Table 3). 
TABLE 3. - SIMPER results: Species responsible for the intergroup dissimilarity in the two main dichotomies. Av.N: mean abundance in the group (ind. $\left.1000 \mathrm{~m}^{-2}\right) ; \delta_{i}(\%)$ : percentage of dissimilarity explained; C. $\delta_{\mathrm{i}}(\%)$ : cumulative $\delta_{\mathrm{i}}(\%)$

Groups I and II - Average dissimilarity $(\delta)=86,49$ Av.N I Av.N II $\delta_{\mathrm{i}}(\%)$ C. $\delta_{\mathrm{i}}(\%)$

\begin{tabular}{lcccc}
\hline Diogenes pugilator & 55.0 & 0.0 & 5.30 & 5.30 \\
Callyonimus maculatus & 0.0 & 14.9 & 2.77 & 8.07 \\
Anapagurus laevis & 9.8 & 439.8 & 2.46 & 10.54 \\
Arnoglossus laterna & 5.0 & 16.7 & 2.10 & 12.63 \\
Pagurus prideaux & 0.1 & 15.9 & 2.06 & 14.69 \\
\hline
\end{tabular}

Groups $\mathrm{II}_{1}$ and $\mathrm{II}_{2}$ - Average dissimilarity $(\delta)=75,62$ Av.N I Av.N II $\delta_{\mathrm{i}}(\%)$ C. $\delta_{\mathrm{i}}(\%)$

\begin{tabular}{lcccc}
\hline Arnoglossus laterna & 29.9 & 0.5 & 3.38 & 3.38 \\
Anapagurus laevis & 798.2 & 1.6 & 2.61 & 5.98 \\
Callyonimus maculatus & 25.7 & 1.7 & 2.57 & 8.55 \\
Turritella communis & 555.2 & 0.0 & 2.53 & 11.09 \\
Ophiura affinis & 2.6 & 78.4 & 2.34 & 13.43
\end{tabular}

The following dichotomy separates the rest of the samples (group II) into two large sub-groups, $\mathrm{II}_{1}$ and $\mathrm{II}_{2}$. Sub-group $\mathrm{II}_{1}$ is made up of strata A and B of sectors 1, 2 and 4, and is characterised by sandy bottom fishes from the shelf, together with the crustacean A. laevis, which was the most abundant species of the assemblage (Table 2). Group $\mathrm{II}_{2}$ includes all samples from stratum $\mathrm{C}$, and station $3 \mathrm{~B}$,

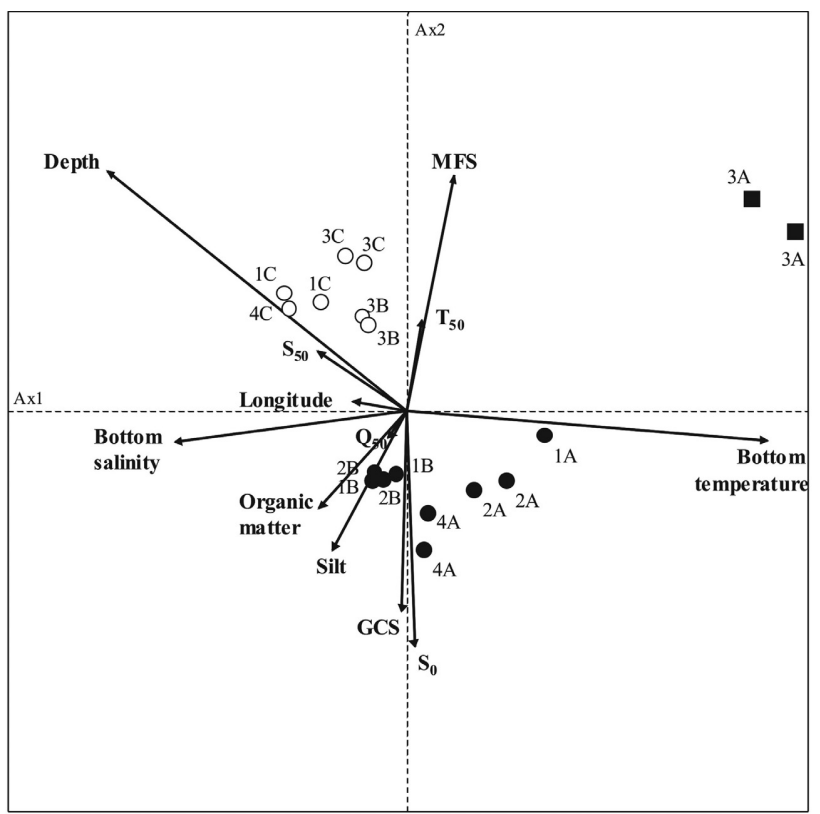

FIG. 3. - CCA biplot of environmental variables versus hauls (cluster groups: solid square $\mathrm{I}$; solid circle $\mathrm{II}_{1}$; empty circle $\mathrm{II}_{2}$ ). Eigenvalues: Ax1: 0.503, Ax2: 0.424; \% variance explained=26.9; significance of Montecarlo test $=0.005$; Temperature and Salinity= near-bottom $\mathrm{T}$ and $\mathrm{S} ; \mathrm{T}_{50}=$ temperature at $50 \mathrm{~m}$ depth; $\mathrm{S}_{50}=$ salinity at $50 \mathrm{~m}$ depth; $\mathrm{Q}_{50}=$ median particle diameter; $\mathrm{S}_{0}=$ sorting coefficient; GCS = weight percentage of gravel and coarse sands $(>500$ $\mu \mathrm{m}) ; \mathrm{MFS}=$ weight percentage of medium, fine and very fine sands $(63-500 \mu \mathrm{m}) ;$ Silt $=$ percentage weight of silt $(<63 \mu \mathrm{m})$ which was the deepest in stratum B. This sub-group is typified by the echinoderm Ophiura affinis, the fish Lepidorhombus boscii, and the crustaceans Philocheras echinulatus, Pontophilus spinosus and Munida sarsi (Table 2), although the most abundant species in the sub-group was the anthozoan $C$. smithii (1203.5 ind. $1000 \mathrm{~m}^{-2}$ in sub-group $\mathrm{II}_{2}$ ), which contributed a lesser percentage to the intragroup similarity, since it is a species with little presence in all the hauls, except in one, in which its presence was massive.

Table 3 shows the species responsible for the separation between sub-groups $\mathrm{II}_{1}$ and $\mathrm{II}_{2}$, all of which were more abundant in sub-group $\mathrm{II}_{1}$, except O. affinis.

Regarding dominance in the communities described, the most abundant species in group I are D. pugilator, A. laevis, A. laterna and Pagurus bernhardus; in sub-group $\mathrm{II}_{1}$ A. laevis, T. communis, Pomatochistus sp., A. laterna, C. maculatus and Pagurus prideaux; and in sub-group $\mathrm{II}_{2} C$. smithii, E. papillosus, O. affinis, Galathea dispersa, $M$. sarsi, P. heterocarpus and G. argenteus.

The direct gradient ordination analysis shows the same discrimination of the three communities as that

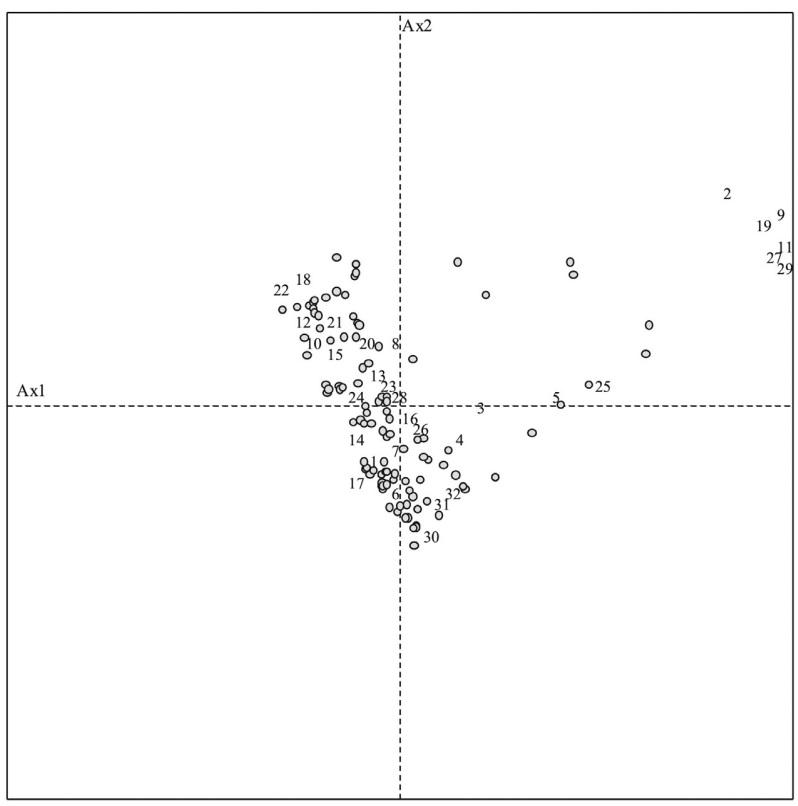

FIG. 4. - CCA plot of species. Points of species cited in the text have been substituted by the following numbers. 1: A. glaber; 2: A. kirchenpaueri; 3: A. laevis; 4: A. laterna; 5: B. luteum; 6: C. crassicornis; 7: C. maculatus; 8: C. smithii; 9: D. pugilator; 10: E. papillosus; 11: E. pusillus; 12: G. argenteus; 13: G. dispersa; 14: G. macrophthalmus; 15: L. boscii; 16: L. depurator; 17: M. merluccius; 18: M. sarsi; 19: M. surmuletus; 20: O. affinis; 21: P. echinulatus; 22: P. heterocarpus; 23: P. prideaux; 24: P. spinosus; 25: P. bernhardus; 26: Pomatoschistus sp.; 27: S. lascaris; 28: S. membranacea; 29: S. officinalis; 30: S. scutata; 31: T. communis; 32: T. ovata 
described above (Figs. 3 and 4). The first discriminatory factor (axis 1) is produced by the opposition of two related variables, bottom water temperature and depth (Fig. 3). This autocorrelation is the reason for the shape of the parabola, called the Guttman effect (Greenacre, 1984), which can be seen in the samples (Fig. 3), though most clearly in the species plot (Fig. 4). The variable near-bottom salinity also contributes with great weight to axis I, in the same direction as depth and opposite to temperature (Fig. 3).

The second discrimination factor is related to the sediment characteristics and opposes homogeneous medium and fine sands (lower values of sorting coefficient) that are poor in organic matter to a mixture of silt and coarse elements that is more heterogeneous (a higher sorting coefficient) and richer in organic matter. Variables such as longitude, median particle size $\left(\mathrm{Q}_{50}\right)$, temperature and salinity at $50 \mathrm{~m}$ show a low weight in both axes (Fig. 3).

Station 3A (group I) is separated from the rest due to its higher temperature, lower depth, and fine sand sediment that is poor in organic matter. This community is characterised by $D$. pugilator, accompanied by the fishes Mullus surmuletus and Solea lascaris, the cephalopod Sepia officinalis, the echinoderm Echinocyanus pusillus and the hydrozoan Aglaophenia kirchenpaueri (Fig. 4).

The samples from group $\mathrm{II}_{1}$ are located in the negative segment of axis 2 , showing their affinity for depths, temperatures and salinities intermediate to the other two groups, and a substrate made up of sediments with a very poor selection (higher $\mathrm{S}_{0}$ ) as a consequence of a mixture of silt and coarse elements, and greater organic contents than those of group I. This group gives the lowest discrimination of species, demonstrated by the greater density of points on the plot in Figure 4, particularly over the stations from stratum B (Fig. 3). Species which contribute to the similarity of groups I and $\mathrm{II}_{1}$ (A. laevis, A. laterna and Pomatochistus sp.; Table 2), together with species which typify one of the groups but which are also abundant in the other, such as Buglossidium luteum, show greater discrimination with respect to samples $3 \mathrm{~A}$, and are situated at the stations of group $\mathrm{II}_{1}$ corresponding to stratum $\mathrm{A}$. The species which characterise group $\mathrm{II}_{1}$ that are more closely related to stratum B include Gaidropsarus macrophthalmus and Callyonimus maculatus (typifying group $\mathrm{II}_{1}$, Table 2), Merluccius merluccius and Alpheus glaber. The species more closely related to station $4 \mathrm{~A}$, characterised by a higher sorting coeffi- cient and a higher percentage of silt, are the gastropod $T$. communis, the bivalve Timoclea ovata and the polychaete Sternaspis scutata.

With greater depths, the lowest temperatures and highest salinities of the environmental range in the study area, subgroup $\mathrm{II}_{2}$ appears, made up of stratum $\mathrm{C}$ and station 3B. This group has a sediment of medium and fine sands, with a sorting coefficient and an organic content that are intermediate to those of the other two groups (Fig. 3). The discrimination of species in this group is higher than that in group $\mathrm{II}_{1}$ (Fig. 4). We can highlight the species that typify the group according to similarity (Table 2): the echinoderm $O$. affinis, the fish $L$. boscii, the Crangonids $P$. echinulatus and $P$. spinosus, and the anomuran M. sarsi.

\section{DISCUSSION}

The results show an absence of significant correlations between environmental variables and the ecological indices, with no linear bathymetric or geographical patterns. The progressive increase in mean species richness with depth described by Olaso (1990) and García-Castrillo and Olaso (1995) for the megabenthic communities in the area was not found in the case of epibenthic communities. On the other hand, a great variability was observed in the species dominances by station. These results coincide with models of patch distribution of communities in which the combination of limitations imposed on species by environmental factors has the effect of partitioning the environment, causing patchiness rather than linear gradients (Pérès, 1982). In the Cantabrian Sea area this effect is highly pronounced since, due to its narrow shelf, strong environmental gradients-and therefore great environmental heterogeneity - are generated, creating a patchy distribution.

The only linear pattern observed was an increase in species richness towards the east in the shallowest stratum, and in the opposite direction in the deepest. The eastward increase in the number of species in the shallowest stratum coincides with previous observations on meridionalisation of the Cantabrian coast, according to which surface warming of waters towards the east favours the presence of meridional species against an exclusively Atlantic fauna in the westernmost part of the coast (FischerPiette, 1938; Ibáñez, 1987, 1988, 1989, 1990). This 
explanation is not so clear for the deepest stratum. One possible reason for the westward increase of species richness may be the fact that, due to its coastal morphology, the western area of the outer Cantabrian shelf (Ribadeo) is an area of retention of hydrographic anomalies (eddies). These eddies have been related to processes of water column production and enrichment of the shelf sedimentary regime (López-Jamar et al., 1992) and-specifically in the Ribadeo area-to hake recruitment (Sánchez and Gil, 2000). Whatever the case, the study of the shelf break communities would involve a more detailed hydrographic and sedimentary study due to its environmental, mainly hydrographic, complexity.

The above-mentioned absence of correlations between the ecological indices and the sedimentary characteristics shows a more diffuse relationship of epibenthic organisms than that described for endobenthic communities, in which lower richness and diversity were observed in coarse or fine sediments, and greater richness in the medium ones (Craig and Jones, 1966; Gray, 1974; Nicolaidou and Papadopoulo, 1989). Zühlke (2000) concluded that sediment composition did not seem to affect epibenthic diversity, and Duineveld et al. (1991) also mentioned that the obscure relationship between epibenthic organisms and sediment type does not allow for a classification based on bottom characteristics. Brown et al. (2001) cited that particle size distributions alone may not always be the best guide to predicting community types, and that other factors, such as seabed morphology and sediment heterogeneity, appeared to have a greater influence. However, other studies suggest that the sediment type is a main factor structuring the epibenthic community (Basford et al., 1989; Rees et al., 1999) and that the epifaunal assemblages may reflect the infaunal communities (Eleftheriou and Basford, 1989). According to Hartnoll (1983), the epifauna is more abundant in gravel sands, but this relationship is not clear in the present study, in which denser sampling would be required to obtain reliable correlations.

In this study, the particle size and organic content pattern was not related to bathymetry and the presence of rías (sea drowned valleys), as it is on the Galician Atlantic shelf (López-Jamar et al., 1992). However, a much more detailed sedimentary determination would be needed to typify the sediment pattern in the area.

Despite there also being a certain interannual variability, the temporal stability of assemblages could be established through multivariate techniques. Depth is the main decisive factor determining the assemblages observed, as a consequence, of the narrow surface of the Cantabrian Sea shelf (Olaso, 1990; Sánchez, 1993; Sánchez and Serrano, 2003). The second factor, the near-bottom temperature, is derived from depth, since depth changes involve subsequent changes in several environmental factors such as pressure, light and temperature. The second gradient is produced by the sedimentary characteristics which, while they do not seem to be determining with respect to the univariate indices, do show a certain discriminatory weight when direct gradient multivariate techniques are used. In this second axis, the heterogeneity of the sediment has been shown to be a factor of discrimination (Brown et al., 2001). Therefore, depth and sediment characteristics may be considered as priority factors in structuring communities, and therefore determining in the presence of species. These conclusions coincide with those obtained in numerous studies (Poore and Mobley, 1980; Basford et al., 1989; Olaso, 1990; Zendrera, 1990; Dahle et al., 1998). Another conclusion is that the communities of the coastal stratum and shelf break are more discriminatory than the shelf communities, showing greater environmental variability in the coastal and shelf break strata, as found in other papers (Abelló et al., 1988; Sánchez, 1993; Sánchez and Serrano, 2003). The formation of the axes from environmental variables perfectly reflects the hydrological characteristics of the Cantabrian Sea, with temperature and salinity opposed, and with a fall in temperature and a rise in salinity with W longitude and depth.

Concerning the faunistic affinities of the groups described, the coastal stratum constitutes a very favourable habitat for the presence of pagurid crabs (Le Danois, 1948), with an outstanding abundance of Pagurus prideaux and to a lesser extent Pagurus bernhardus (Selbie, 1921; Basford et al., 1989; Olaso, 1990) to which, in this paper, we can add smaller species, such as Anapagurus laevis and Diogenes pugilator, as dominant pagurid species on the inner and middle Cantabrian shelf.

The coastal community of fine poor sands (group I) is characterised by these two last species of pagurids, together with fish species. Diogenes pugilator is a crustacean of fine sand and shallow depth (Falciai and Minervini, 1995; Sánchez-Mata et al., 1993), while A. laevis, more abundant in group $\mathrm{II}_{2}$, is a species of wide bathymetric distribution (Ingle, 
1993) with a preference for depths of up to $100 \mathrm{~m}$ (Falciai and Minervini, 1995; Jennings et al., 1999) and sandy bottoms with a broad size range and sorting coefficient (Lagardère, 1973; García-Gómez, 1994). Regarding fishes, Arnoglossus laterna is a species with a wide bathymetric range of 50-200 m (Sánchez, 1993) and a preference for sediments containing mud (Freire et al., 1993), and this explains its importance in the two shallower clusters for bathymetric reasons, and in the shelf group with coarse/silt mixed sediments for sedimentary reasons. On the other hand, Buglossidium luteum is a species restricted to sandy bottoms of the inner shelf, at 50-100 m (Sánchez, 1993), which gives it a greater weight in the shallowest station group. This station group has highly mobile sands which explain its low indices and the differentiation from the rest of the stations. According to the stability-time hypothesis (Sanders, 1968), habitats exposed to highly hydrodynamic variable conditions have less stable sediments and thus a less diverse community, avoiding the development of long-lived species (Hiscock, 1983).

The shelf stratum with mixed coarse/silt sediments is characterised by fishes, such as A. laterna, and the spotted dragonet Callyonimus maculatus. This latter species is described as common in sediments with the presence of mud at between 125 and 250 m (Sánchez, 1993). The ordination analysis included shelf species from fine sandy bottoms with the presence of mud, such as Chlorotocus crassicornis or Alpheus glaber (Lagardère, 1970 and 1973; Smaldon, 1979; Holthuis, 1980; Sorbe, 1987; Olaso, 1990), species with an affinity for the presence of silt with a reasonable proportion of gravel, such as Turritella communis (Yonge, 1946), silt affined species, such as Sternaspis scutata (Glémarec, 1969; Amoureux, 1971), and eurybathic species in this study depth range, such as Solenocera membranacea and Liocarcinus depurator (Lagardère, 1973; Sorbe, 1987; Abelló et al., 1988; Olaso, 1990). These eurybathic species are located practically at the centroid of the analysis, also showing a low discrimination by the sedimentary gradient. Pontophilus spinosus is located between the shelf group and that of the shelf edge, showing its affinity for the outer shelf and lower optimum depth than another related species, Philocheras echinulatus (Abelló et al., 1988; Olaso, 1990).

The shelf break group, more closely related to medium, fine and very fine sands analogous to the sands at the shelf break of the nord-Gascogne slope described by Le Danois (1948) and Glémarec (1969), is characterised by the echinoderm Ophiura affinis, common in muddy fine and gravelly sands (Holme, 1953; Moyse and Tyler, 1990), and the fish Lepidorhombus boscii, which is a species with a preference for depths between 250 and $400 \mathrm{~m}$ (Sánchez, 1993). Munida sarsi is one of the most abundant species on the shelf, with a greater density at $275 \mathrm{~m}$ (Olaso, 1990). The crangonid P. echinulatus is considered characteristic of the shelf edge (Olaso, 1990).

These faunistic patterns of spatial distribution are comparable to those obtained by Martínez and Adarraga (2001) for the Basque Cantabrian shelf, by Lauroz (1993) for the French Atlantic shelf, and by Abelló et al. (1988) for decapod crustacean assemblages of the northwest Mediterranean, with the obvious biogeographical differences, of shelf width and sediment distribution.

Obtaining taxonomic lists and clarifying the spatial and interspecific relationships of the epibenthic organisms will be of great help in understanding ecosystems of areas submitted to fishing disturbance processes, such as the Cantabrian Sea. This information will serve as a reference for monitoring the environmental changes resulting from trawl fishery. In addition, the quantified information on small epibenthic organisms represents an advance in the knowledge of the behaviour of the trophic selection of commercial species, by comparison with stomach contents (Serrano et al., 2003a, b).

Future works will attempt to further the study of these epibenthic communities and complete it with the endobenthic communities, with the aim of obtaining full information on Cantabrian shelf ecosystems.

\section{ACKNOWLEDGEMENTS}

This study was made possible thanks to the invaluable work of all the participants in the Cantabrian bottom trawl surveys and the crew of the RV "Cornide de Saavedra”. It was partially supported by the Marcelino Botín Foundation.

\section{REFERENCES}

Abelló, P., F.J. Valladares and A. Castellón. - 1988. Analysis of the structure of decapod crustacean assemblages off the Catalan coast (North-West Mediterranean). Mar. Biol., 98: 39-49. 
Amoureux, L. - 1971. Contribution à la connaissance de la faune bentique du golfe de Tarente (Italie). Annélides polychètes récoltées par l'Albatross en 1966-1967. Rapp. Comm. Int. Mer Méditer., 20: 201-203.

Basford, D.J., A. Eleftheriou and D. Rafaelli. - 1989. The epifauna of the Northern North Sea $\left(56^{\circ}-61^{\circ} \mathrm{N}\right)$. J. Mar. Biol. Ass. UK, 69: 387-407.

Brown, C.J., A.J. Hewer, W.J. Meadows, D.S. Limpenny, K.M. Cooper, H.L. Rees and C. Vivian. - 2001. Mapping of gravel biotopes and an examination of the factors controlling the distribution, type and diversity of their biological communities. DEFRA Research Project AE0908, Final Report. Centre for Environmental, Fisheries and Aquaculture Science, Sci. Ser. Tech. Rep., 14: 1-43.

Clarke, K.R. and R.M. Warwick. - 1994. Change in marine communities: an approach to statistical analysis and interpretation. Plymouth Marine Laboratory.

Craig, G.Y. and N.S. Jones. - 1966. Marine benthos, substrate and palaeoecology. Palaeontol., 9: 30-38.

Dahle, S., S.G. Denisenko, N.V. Denisenko and S.J. Cochrane. 1998. Benthic fauna in the Pechora Sea. Sarsia, 83: 183-210.

Duineveld, G.C.A., A. Künitzer, U. Niemann, P.A.W.J. Wilde and J.S. Gray. - 1991. The macrobenthos of the North Sea. Neth. J. Sea Res. 28: 53-65.

Eleftheriou, A. and D.J. Basford. - 1989. The macrobenthic infauna of the offshore northern North Sea. J. Mar. Biol. Ass. UK, 69: 123-143.

Falciai, L. and R. Minervini. - 1995. Crustáceos Decápodos de Europa. Ediciones Omega, Barcelona.

Field, J.G., K.R. Clarke and R.M. Warwick. - 1982. A practical strategy for analysing multispecies distribution patterns. Mar. Ecol. Prog. Ser., 8: 37-52.

Fischer-Piette, E. - 1938. Sur le caractère meridional du bios intercotidal du golfe de Gascogne. Comp. Rend. Somm. Séanc. Soc. Biogeogr., 15: 61-65.

Freire, J., L. Fernández, R. Muiño and E. González-Gurriarán. 1993. Análisis geoestadístico de la distribución de crustáceos y peces megabentónicos en la Ría de Ferrol (Galicia, NO España). Publ. Esp. Ins. Esp. Oceanogr., 11: 259-266.

García-Castrillo, G. and I. Olaso. - 1995. Composition and structure of the invertebrates megabenthos in the platform of the Cantabrian Sea. ICES Mar. Sci. Symp., 199: 151-156.

García-Gómez, J. - 1994. The systematics of the genus Anapagurus Henderson, 1886, and a new genus for Anapagurus drachi Forest, 1966 (Crustacea: Decapoda: Paguridae). Zool. Verh. Leiden, 295: $131 \mathrm{pp}$.

Glémarec, M. - 1969. Le plateau continental nord-Gascogne et la Grande Vasiere. Etude bionomique. Rev. Trav. Inst. Pêches Marit., 33: 301-310.

Gray, J.S. - 1974. Animal sediment relationships. Oceanogr. Mar. Biol. Ann. Rev., 12: 223-261.

Greenacre, M. - 1984. Theory and Applications of Correspondence Analysis. Academic Press, London.

Hartnoll, K. - 1983. Substratum. In: R. Earll, D.G. Erwin (eds.), Sublittoral ecology. The ecology of the shallow sublittoral benthos, pp. 97-124. Clarendon Press, Oxford.

Hiscock, K. - 1983. Water movement. In: R. Earll, D.G. Erwin (eds.), Sublittoral ecology. The ecology of the shallow sublittoral benthos, pp. 58-96. Clarendon Press, Oxford.

Holme, N.A. - 1953. The biomass of the bottom fauna in the English Channel off Plymouth. J. Mar. Biol. Ass. UK, 32: 1-49.

Holthuis, L.B. - 1980. FAO species catalogue. Vol. 1. Shrimps and prawns of the world. An annoted catalogue of species of interest to fisheries. FAO Fish. Synop., 125: 1-271.

Ibáñez, M. - 1987. El Golfo de Vizcaya: Meridionalización o continentalización. Abissalia, 1: 11-12.

Ibáñez, M. - 1988. Evolución a medio plazo de las temperaturas del agua de mar frente a la costa vasca. Lurralde, 11: 431-436.

Ibáñez, M. - 1989. Implicaciones biogeográficas de la continentalización de la costa vasca. Lurralde, 12: 71-101.

Ibáñez, M. - 1990. El Golfo de Vizcaya: Meridionalización "versus" continentalización. Bentos, 6: 491-501.

Ingle, R. - 1993. Hermit crabs of the Northeastern Atlantic ocean and Mediterranean Sea. An illustrated key. Natural Hystory Museum Publications. Chapman Hall.

Jennings, S., J. Lancaster, A. Woolmer and J. Cotter. - 1999. Distribution, diversity and abundance of epibenthic fauna in the
North Sea. J. Mar. Biol. Ass. UK, 79: 385-399.

Jongman, R.H.G., C.J.F. Ter Braak and O.F.R. Van Tongeren. 1987. Data analysis in community and landscape ecology. Pudoc Wageningen.

Krebs, C.J. - 1989. Ecological Methodology. Harper and Row, Publishers. New York. Lagardère, J.P. - 1970. Les crevettes du golfe de Gascogne (région sud). Tethys, 1: 1023-1048.

Lagardère, J.P. - 1973. Distribution des décapodes dans le sud du Golfe de Gascogne. Rev. Trav. Inst. Pêches Marit., 37: 77-95.

Lauroz, K. - 1993. Description et cartographie des associations d'espèces vagiles (poissons et invertébres) dans le golfe de Gascogne et sur le plateau celtique. D.E.A. en Océanologie Biológique: Sciences de l'Environment marin. Univ. d'Aix Marseille II.

Le Danois, S. - 1948. Les profendeurs de la mer. Payot, Paris.

López-Jamar, E., R.M. Cal, G. González, R.B. Hanson, J. Rey, G. Santiago and K.R. Tenore. - 1992. Upwelling and outwelling effects on the benthic regime of the continental shelf off Galicia, NW Spain. J. Mar. Res., 50: 465-488.

Martínez, J. and I. Adárraga. - 2001. Distribución batimétrica de comunidades macrobentónicas de sustrato blando en la plataforma continental de Guipúzcoa (golfo de Vizcaya). Bol. Inst. Esp. Oceanogr., 17: 33-48.

Moyse, J. and P.A. Tyler. - 1990. Echinodermata. In: P.J. Hayward, J.S. Ryland (eds.), The Marine Fauna of the Bristish Isles and North-West Europe. Vol. 2, 839-871. Oxford Science Publ.

Nicolaidou, A. and K.N. Papadopoulou. - 1989. Factors affecting the distribution and diversity of polychaetes in Amvrakikos Bay, Greece. Pubbl. Staz. Zool. Napoli I, 10: 193-204.

Olaso, I. - 1990. Distribución y abundancia del megabentos invertebrado en fondos de la plataforma Cantábrica. Publ. Espec. Inst. Esp. Oceanogr., 1: 1-128.

Pérès, J.M. - 1982. Structure and dynamics of assemblages in the benthal. In: O. Kinne, (ed.), Marine Ecology. Vol. 5, Part I, Chapt 5, pp. 119-185. John Wiley, Sons Ltd.

Poore, G.C.B. and M.C. Mobley. - 1980. Canonical correlation of marine macrobenthos survey data. J. Exp. Mar. Biol. Ecol., 45: 37-50.

Rees, H.L., M.A. Pendle, R. Waldrock, D.S. Limpenny and S.E. Boyd. - 1999. A comparison of benthic diversity in the North Sea, English Channel and Celtic seas. I.C.E.S. J.Mar. Sci., 56: 228-246.

Sánchez, F. - 1993. Las comunidades de peces de la plataforma del Cantábrico. Publ. Espec. Inst. Esp. Oceanogr., 13: 1-137.

Sánchez, F., F. de la Gándara and R. Gancedo. - 1995. Atlas de los peces demersales de Galicia y el Cantábrico. Otoño 1991-1993. Publ. Esp. Inst. Esp. de Oceanogr., 20: 1-99.

Sánchez, F. and J. Gil. - 2000. Hydrographic mesoscale structures and Poleward Current as a determinant of hake (Merluccius merluccius) recruitment in southern Bay of Biscay. I.C.E.S. J. Mar. Sci., 57: 152-170.

Sánchez, F. and A. Serrano, A. - 2003. Variability of demersal fish communities of the Cantabrian Sea during the decade of the 1990s. ICES Mar. Sci. Symp., 219: 249-260.

Sánchez Mata, A., J. Mora, J.M. Garmendia and M. Lastra. - 1993. Estructura trófica del macrozoobentos submareal de la ría de Ares-Betanzos. I: Composición y distribución. Publ. Esp. Ins. Esp. Oceanogr., 11: 33-40.

Sanders, H.L. - 1968. Marine benthic diversity: a comparative study. Amer. Nat., 102: 243-282.

Selbie, C.M. - 1921. The Decapoda Reptantia of the coasts of Ireland. Part 2. Paguridae. Scientific Investigations of the Fisheries Branch. Department of Agriculture and Technical Instruction for Ireland for $1921, \mathrm{n}^{\circ} 1,68 \mathrm{pp}$.

Serrano, A., F. Velasco, I. Olaso and F. Sánchez. - 2003a. Macrobenthic crustaceans in the diet of demersal fish in the Bay of Biscay in relation to abundance in the environment. Sarsia, 88: $36-48$.

Serrano, A., F. Velasco and I. Olaso. - 2003b. Polychaete annelids in the diet of demersal fish from the southern shelf of the Bay of Biscay. J. Mar. Biol. Ass. UK, 83: 619-623.

Smaldon, G. - 1979. British Coastal Shrimps and Prawns. Synopses of the British fauna (n.s.), $\mathrm{n}^{\circ} 15$. Academic Press.

Sorbe, J.C. - 1987. Contribución al conocimiento de la biología de los crustáceos decápodos Natantia en la plataforma continental Aquitana (suroeste de Francia). Cuad. Marisq. Publ. Tec., 11: $11-30$. 
Ter Braak, C.J.F. - 1987. The analysis of vegetation-environment relationships by canonical correspondence analysis. Vegetatio, 69: 69-77.

Ter Braak, C.J.F. - 1988. Partial canonical correspondence analysis. In: Bock, H.H. (ed.), Classification methods and related methods of data analysis, pp. 551-558. North Holland, Amsterdam.

Ter Braak, C.J.F. and P.F.M. Verdonschot. - 1995. Canonical correspondence analysis and related multivariate methods in aquatic ecology. Aquat. Sci., 57: 153-289.

Verdonschot, P.F.M. and C.J.F. Ter Braak. - 1994. An experimental manipulation of oligochaete communities in mesocosms treated with chlorophytos or nutrient additions: multivariate analyses with Monte Carlo permutation tests. Hydrobiol., 278: 251-266.
Yonge, C.M. - 1946. On the habits of Turritella communis Risso. J. Mar. Biol. Ass. UK, 26: 377-380

Zendrera, N. - 1990. Typologie du golfe de Gascogne á partir de l'analyse des associations faunistiques. D.E.A. en Océanologie Biologique: Ecosystems marins. Option paramétrisation et modélisation. Univ. Pierre et Marie Curie (Paris VI).

Zühlke, R. - 2000. Monitoring biodiversity of epibenthos and demersal fish in the North Sea and Skagerrak. EC Project: 98/021. Monitoring Report 2000 to the Commission of the European Community.

Received June 27, 2002. Accepted November 24, 2004.

APPENDIX I. - Complete list of species and mean abundance $\left(\mathrm{n}^{\mathrm{o}}\right.$ ind. $\left.\cdot 1000 \mathrm{~m}^{-2}\right)$ by stratum

Porifera

Axinella egregia

Axinella sp.

Mycale lingua

Myxilla rosacea

Phakellia ventilabrum

Spongia officinalis

Spongionella pulchella

Suberites sp.

Sycon ciliatum

\section{Cnidaria}

Abietinaria abietina

Actinauge richardi

Actinia cari

Adamsia carcinopados

Aglaophenia kirchenpaueri

Aglaophenia pluma

Aglaophenia tubulifera

Alcyonium digitatum

Amphisbetia operculato

Calliactis parasitica

Caryophyllia smithii

Diphasia alata

Epizoanthus papillosus

Funiculina quadrangularis

Hydractinia echinata

Lytocarpia myriophyllum

Nemertesia ramosa

Pennatula rubra

Plumularia setacea

Polyplumularia flabellata

Pteroeides griseus

Serturalella polyzonias

\section{Polychaeta}

Acholoe squamata

Amphicteis gunneri

Aphrodita aculeata

Arabella iricolor

Chloeia venusta

Clymene sp.

Eteone barbata

Euclymene sp.

Glycera rouxii

Hyalinoecia tubicola

Hydroides norvegica

Laetmonice filicornis

Lanice conchylega

Nephtys cirrosa

Nephtys hombergi

Nephtys incisa

Nereis fucata

Notomastus profundus

Orbinia cuvieri

Petaloproctus sp.
A

B

1.95

7.07

0.49

0.24

1.46

0.24

0.24

0.24

1.10

1.22

1.95

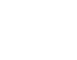

7.81

$\begin{array}{ccc}2.34 & 2.07 \\ 0.24 & \end{array}$

8.61

2.93

14.15

1.05

0.24

10.54

10.25

0.24

490.19

24.03

1.83

28.30

0.24

5.29

7.29

19.10

1.71

0.49

0.41

4.46

0.73

3603.56

0.24

3.78

293.90

2.20

1.46

2.07

0.37

11.22

0.24

0.49

0.02

0.49

0.24

0.24

0.49

0.49
0.24

0.24

1.22

102.15

0.61

0.32

5.20

0.05

0.24

0.37

0.24

0.24

0.24

0.24

0.61

0.49

0.37

0.98
Phyllodoce groenlandica Serpula vermicularis

Sternaspsis scutata

Sthenelais limicola

Sthenolepis yhleni

Syllis parapari

Terebellides stroemi

Sipuncula

Golfingia vulgaris

Phascolion strombii

\section{Crustacea}

Alpheus glaber

Anapagurus bicorniger

Anapagurus hyndmani

Anapagurus laevis

Anapagurus pusillus

Atelecyclus rotundatus

Bathynectes maravigna

Chlorotocus crassicornis

Cirolana cranchii

Corystes cassivelaunus

Cymodoce truncata

Dichelopandalus bonnieri

Diogenes pugilator

Ebalia cranchii

Epimeria parasitica

Eurydice affinis

Eurynome aspera

Galathea dispersa

Galathea intermedia

Goneplax rhomboides

Heterocrypta maltzani

Inachus dorsettensis

Inachus leptochirus

Liocarcinus depurator

Liocarcinus holsatus

Liocarcinus marmoreus

Liocarcinus pusillus

Lophogaster typicus

Macropipus tuberculatus

Macropodia rostrata

Macropodia tenuirrostris

Maja squinado

Monodaeus couchii

Munida intermedia

Munida iris

Munida sarsi

Nephrops norvegicus

Pagurus alatus

Pagurus bernhardus

0.49 arus chevreuxi

Pagurus excavatus

Pagurus prideaux

Pagurus pubescentulus
A

1.63

8.90

1.71

0.24

0.24

3.37

B

C

0.49

30.25

0.24

6.83

1.95

0.98

11.30

11.95

64.65

894.80

0.98

6.10

2.20

0.24

0.02

33.91

7.86

0.49

4.51

0.05

5.73

0.73

0.02

1.34

8.03

0.05

24.64

2.37

21.08

0.05

0.24

1.46

0.24

5.37

0.24

0.24

3.05

12.93

7.03

32.62

5.81

2.27

1.54

0.24

1.22

0.98

2.44

$\begin{array}{ll}2.98 & 2.44 \\ & 0.49\end{array}$

1.95

11.54

76.12

2.07

13.91

0.24

2.51

58.43

1.61

0.90

0.24

2.22

0.98

18.74

0.49 
Pandalina brevirostris

Philocheras echinulatus

Plesionika heterocarpus

Polybius henslowi

Pontophilus spinosus

Processa canaliculata

Processa nouveli

Rissoides desmaresti

Scalpellum scalpellum

Scyllarus arctus

Solenocera membranacea

Xantho pilipes

\section{Mollusca}

Acteon tornatilis

Alloteuthis media

Antalis entalis

Aperiovula adriatica

Aporrhais pespelicani

Aporrhais serresianus

Arminia trigina

Astarte sulcata

Bathypolipus sponsalis

Bela ornata

Bela sp.

Calliostoma granulatum

Charonia lampax

Chlamyx varia

Colus gracilis

Colus jeffreysianus

Comarmondia gracilis

Coralliophila squamosa

Corbula gibba

Crassopleura maravignae

Cuspidaria cuspidata

Dosinia exoleta

Eledone cirrhosa

Epitonium clathrus

Epitonium turtonis

Fusinus rostratus

Galeodea rugosa

Glycimeris glycimeris

Hiatella arctica

Hinia reticulata

Lunatia catena

Lunatia fusca

Lunatia pulchella

Mytilus edulis

Neptunea contraria

Nucula sulcata

Ocenebra erinaceus

Octopus salutii

Octopus vulgaris

Pseudamussium septenradiatum

Pseudosimnia carnea

Pteria hirundo

Pygnodontha cochlear

Rondeletiola minor

Rossia macrosoma

Scaphander lignarius

Sepia elegans

Sepia officinalis

Sepia orbignyana

Sepietta oweniana

Sepiola atlantica

Sepiola sp.

Spisula subtruncata

Tellina donacina

Timoclea ovata

Turritela communis

Venus casina

Venus striatula

Venus verrucosa

$\begin{array}{ccc}\mathbf{A} & \mathbf{B} & \mathbf{C} \\ & & 31.47 \\ 1.05 & 3.24 & 12.44 \\ & 0.37 & 16.35 \\ 113.78 & 1.66 & 0.73 \\ 6.20 & 4.20 & 14.93 \\ 18.20 & 0.85 & 10.39 \\ & & 6.83 \\ & & 0.24 \\ 1.95 & 4.46 & \\ 0.98 & 0.49 & 0.81 \\ 3.66 & 1.54 & 4.15 \\ & & 1.22\end{array}$

0.05

6.46

23.66

0.24

0.56

0.49

1.95

0.24

0.24

0.73

0.98

0.24

0.24

0.24

1.46

0.24

0.24

6.78
0.37

1.22

0.24

1.05

0.98

0.98

1.71

1.54

6.22

0.37

4.34

0.49

0.24

0.73

0.73

0.73

0.24

0.24

0.24

0.73

10.37

0.02

9.20

0.24

0.73

0.93

18.25

1.22

0.24

1.22

2.68

2.07

1.54

0.24

0.24

0.24

0.24

1.46

0.49

0.24

1.15

9.71

0.24

0.24

0.41

0.24

0.24

12.69

0.24

0.24

0.24

0.24
0.49

3.22

0.61

0.85

0.24

0.49

0.61

5.49

0.73

1.34

0.24

0.24

1.83

1.95

0.24

0.66
0.24

1.95

25.54

873.65

6.03

0.24

0.49
Echinodermata

Anseropoda placenta

Astropecten auranticus

Astropecten irregularis

Brissopsis lyrifera

Echinaster sepositus

Echinocardium cordatum

Echinocyamus pusillus

Echinus acutus

Holothuria forskali

Leptometra celtica

Leptosynapta inhaerens

Luidia ciliaris

Luidia sarsi

Marthasterias glacialis

Ophiothrix fragilis

Ophiura affinis

Ophiura ophiura

Psammechinus miliaris

Stichastrella rosea

Stichopus regalis

Trachythyone elongata

Trachythyone tergestina

Tunicata

Corella paralelograma

A

B

C

0.24

0.24

0.98

1.85

0.24

0.02

0.24

1.78

0.24

4.00

2.44

7.64

Fishes

Argentina sphyraena

Arnoglossus imperialis

Arnoglossus laterna

Aspitrigla cuculus

Bathysolea profundicola

Blennius ocellaris

Buglossidium luteum

Callionymus lyra

Callionymus maculatus

Capros aper

Cepola rubescens

Chelidonichthys gurnardus

Chimaera monstrosa

Conger conger

Crystallogobius linearis

Deltentosteus quadrimaculatus

Gadiculus argenteus

Gaidropsarus macrophthalmus

Galeus melastomus

Labrus bimaculatus

Lepidorhombus boscii

Lepidorhombus whiffiagonis

Lesueurigobius friesii

Leucoraja naevus

Lophius budegassa

Lophius piscatorius

Maurolicus muelleri

Merluccius merluccius

Microchirus variegatus

Micromesistius poutassou

Molva dipterygia

Mullus surmuletus

Pagellus bogaraveo

Phycis blennoides

Pomatoschistus sp.

Scyliorhinus canicula

Serranus cabrilla

Solea lascaris

Solea vulgaris

Trachinus draco

Trigla lucerna

Trisopterus luscus

Trisopterus minutus

Zeus faber

1.71

$0.24 \quad 1.95$

5.61

0.24

0.24

0.02

0.24

0.24

21.40

9.81

0.24

0.49

1.22

3.17

0.73

0.24

0.81

6.83

19.74

2.81

1.71

0.24

25.30

0.24

0.24

0.49

8.61

1.83

0.24

0.37

3.05

0.37

97.58

2.27

0.24

5.86

0.44 
